\title{
CASHLESS SOCIETY: DRIVE'S AND CHALLENGES IN NIGERIA
}

\author{
Maitanmi Olusola ${ }^{1}$, Awodele Oludele ${ }^{2}$, Ogbonna Chibueze $^{3}$, and Osundina \\ Samuel $^{4}$ \\ ${ }^{1}$ Department of Computer Science, School of Computing and Engineering, Babcock \\ University, Ilisan Remo, Ogun State, Nigeria. \\ maitanmi@yahoo.com \\ ${ }^{2}$ Department of Computer Science, School of Computing and Engineering Babcock \\ University, Ilisan Remo, Ogun State, Nigeria. \\ delealways@yahoo.com \\ ${ }^{3}$ Department of Computer Science, School of Computing and Engineering Babcock \\ University, Ilisan Remo, Ogun State, Nigeria. \\ acogbonna069yahoo.com \\ ${ }^{4}$ Department of Basic Science, School of Science and Technology, Babcock University, \\ Ilisan Remo, Ogun State, Nigeria \\ sosundinalyahoo. com
}

\begin{abstract}
The purpose of this paper is to examine how we can achieve a cashless society in Nigeria especially given her infrastructure deficits. This study examines the cashless economic system so as to assess its feasibility in Nigeria with regards to timeless, preparedness and adequacy against the backdrop of our level of development both technologically and educationally. Nigeria has continued to evolve in different realms. The economy is being reformed, the institutions are being reshaped and laws are being re-examined so as to reposition the nation to take its rightful position in the international community. As a way of fasttracking the Nigerian economy so as to be among the first 20 world economies come 2020, Nigeria proposed 2012 for the adoption of the cashless economy system starting with Lagos State but could not realized its objective. The study used structured questionnaire as a means of data collection and the collected data were analyzed using simple percentage procedure. The results indicate that: majority of Nigerians are already aware of the policy and majority agree that the policy will help fight against corruption/money laundering and reduce the risk of carrying cash and can also foster economic growth. Major problems envisaged that can hinder the implementation of the policy are: cyber fraud, limited point of sales and numeracy illiteracy. Based on the findings some recommendations made are: the government should adopt a different strategy to educate the non-literate Nigerians about the cashless economy; and the Federal Government of Nigerian should establish a Cybercrime law.
\end{abstract}

\section{KEYWORDS}

ATM, Base Money, Cashlite, Cashless, and POS. 


\section{INTRODUCTION}

Over the course of history, there have been different forms of payment systems. Originally, barter was quite common. Eventually, various forms of money were introduced. In the mid-twentieth century, charge cards debuted [2]. Ever since then, pundits have been predicting the demise of paper instruments and the emergence of a 'cashless society' A cashless society could be defined as one characterised by few notes and coins in circulation issued by a Central bank[16].

Within the last decade or so, our world has become rapidly more digitized. For example, we now have internet purchases, and social interactions made via short message service (SMS), e-mails and social networks on the Internet. Two important factors that have contributed to this development are the use of mobile phones, and the use of the Internet. We are more 'on the go' than ever and get things done while we are on the go via our digital services turning the world to a mobile village.A part of the above mentioned digital purchases is digital payments. And when everything else is mobile, the payments have to be mobile too; we have to be able to pay for goods and services no matter where we are. Thus there is a need for an electronic wallet, an ewallet, with which mobile payments can be made.Mobile payments are defined as "payment for goods, services and bills with a mobile device such as mobile phone, smart-phone, or personal digital assistant (PDA) by taking advantage of wireless and other communication technologies" [6].Today, we still pay cash and checks, but several other payment instruments, such as credit and debit cards are widely used. The use of paper money is declining, but at a slow pace. A success story today in Nigeria of electronic payment is the Automated Teller Machine (ATM) which is used by consumers primarily as cash dispenser a usage that has continued to grow. The basics of mobile payments have been describe and it is relevant to pay attention to what kind of mobile payment technologies that exist today in order to be able to assess the introduction of a cashless society through mobile payments.From the foregoing challenges, the objectives of this study therefore are to examine the benefits of the cashless economy, the essential elements of the cashless economy and assess the preparedness for the implementation of the cashless economy by Nigeria. This is anticipated will help bridge the gap between recent perceptions about the cashless economy and the actual operations of the system. To achieve these objectives this study is divided into five sections. Following this introduction, Section II, examines existing literature on cashless economy, Section III, presents the methodology employed in collecting and analysing data, Section IV, presents an analysis of the collected data; and Section V, deals with the conclusion and recommendations drawn up from the study.

\section{REVIEW OF LITERATURE}

During the last couple of decades numerous solutions for payment methods have been developed. Some of these developments are characterised as mobile ways of transferring money digitally; Short Message Service (SMS), Quick Response (QR)-codes, and Near Field Communication (NFC).

\subsection{SMS}

SMS has existed since 1992 and a message can only contain 160 characters, which limits the contents relatively. SMS's are used in areas such as in Television shows for buying tickets for transportation, or between friends. The technology always works as remote communication via Global Systems of Communication (GSM) and EDGE/UNITS networks among others. 


\subsection{QR-code}

A QR-code is a 2D barcode that can be scanned by a mobile phone, using a network on the mobile phone's browser. In the same manner, the user enters his credit card information on the webpage to be charge this way. A QR-code can also be used as verification for a purchase such as in boarding pass. The code can be scanned directly on the mobile phone by a flight line agent.However, a QR-code payment is still a strange thing to Nigerian financial landscape.

\subsection{NFC}

NFC is a new and more sophisticated technology within the Radio Frequency Identification (RFID) technology, which is a subset of RF technology. It is based on a wireless, but close proximity transmission from a mobile phone to another or to a reader at a maximum range of $10 \mathrm{~cm}$. A research carried out by [2], and [7], suggested that the increased use of cashless payment systems could lead to a cashless society; a topic eagerly debated among information technology (IT) students, politicians, companies and banks. In a cashless society, payments can be made at unmanned vending machines, at manned point of sale (POS), over the Internet, using mobile phones, personal digital assistants (PDA's), smart cards and other electronic payment systems such as credit and debit cards. The creation of such a society creates a complex challenge. If it were to succeed, it could have a positive effect on the economy, crime, health and the environment. In a time when the welfare state's future is up for discussion, sound financial savings and efficiency improvements are important conditions for the future welfare level.However, paying is an inherently social interaction each of us participates in daily, and therefore that type of paying is so basic, that it has proved difficult to change. The following sections will take a look at three periods: ancient methods of payment solution, contemporary works that brings us close to having a cashless society; and the future up and coming electronic payments systems.

\subsection{ANCIENT METHODS OF PAYMENT}

In the early 2000's early mobile contents and services such as ring tones and logos were successful, and made mobile payment services a hot topic that even survived the burst of Internet activities [12].This fact, in coupled with the wide use of mobile phones and the proliferation of mobile telecommunications technology, formed the basis for the development of mobile payment solutions. Later, mobile payments were suggested as an alternative for micro-payments at POS, where the use of cash had been declining for many years. Lots of mobile and electronic payment solution $\mathrm{s}$ have been introduced ever since, but most of them have failed or have had a low penetration rate [11] and [6].It needs to be noted the concept of 'payment' is a basic act which cannot be changed just like that considering that payment is transacted in almost the same way worldwide, and would therefore be a serious challenge if each country had its own electronic payment system. Further complications arise when companies additionally develop their own electronic payment systems, such as those for busses, subways and petrol. [11] supports this argument and states that payment solutions have to be standardized in order to be adopted by the consumers.One of the more successful electronic payment systems is 'PayPal', which was launched as far back as 1999. Initially, PayPal enabled people to perform transactions of small payments by means of e-mails and PDA's (personal digital assistance). Since then, PayPal's system has been re-designed and extended several times, and was acquired by eBay in July, 2002 [12]. Today PayPal has more than 220 million accounts and is predicted to surpass its eBay in 
revenue in 2014. Moreover, its sponsors are already experimenting in the area of mobile payments through a partnership with a start-up that provides stickers for mobile phones that can link the phone to some special payment terminals in the stores [10]. The two other electronic payment systems that have had, and still have success are the Oyster Card in London which was introduced in 2003 [9] and the Octopus Card in Hong Kong which was launched in 1997 and is available in different types that fit different needs and age [13].

\subsection{CONTEMPORARY WORKS}

Besides PayPal, the octopus card and Oyester cards which have been successful for several years also Visa PayWave and MasterCard Paypass were also introduced in 2003 and 2007 respectively. PayWave and Paypass are contactless payment technologies which both uses RFIDC-technologywhich means that you do not have to swipe your card or insert it into another drive to pay. The above were primarily introduced as smart card technology, but have since been extended to include key fobs and Near Field Communication (NFC) enabled mobile phones. Both PayPass and PayWave are relatively young technologies and not very much like PayPal, Oyster or Octopus Card. PayPal is so far Internet based, while PayPass and PayWave are not. PayPass and PayWave aim to pay for a broad variety of goods and services and could therefore to a great extent substitute for the Visa, and Master Cards, whereas, the Oyster and Octopus cards focus on the niche of fares for mass transit systems, goods and services needed 'on the go'. However, Visa is not the only one trying to get a foothold on the mobile payments market. In the summer 2010, Apple hired an expert specialized in NFC and mobile payment to turn iPhone into wallet.

Third player in the field of mobile payments is Isis, a joint venture founded in 2010 and made up of AT \& T Mobility, Verizon Wireless and T-Mobile, USA. The focus of Isis is to build a mobile payment network based on NFC technology, which makes it possible to make point of sale (POS) purchases through mobile phones.

\subsection{ADVANTAGES OF CASHLESS PAYMENT SYSTEM}

A lot has been said about the convenience of electronic cash, the time it saves for individuals, and the ease of access resulting in money being instantly available for us without having to be carried around while currency exchange will be largely unnecessary.A cashless society will experience a high degree of control as the move from cash to electronic money (electronic credit) is a part of a well-organised attempt to unify the world and control it through its currency. It will be a big booster for bringing the economic uniformity in the world.A cashless society will further enhance the globalization that characterise our present time. The computerised systems can be used to reduce the amount of paper trail. Also replacing paper cash with cashless credits or electronic money transfers can at least minimize crime, illegal drug trade, terrorism, illegal immigration, human trafficking, and corruption. A cashless society will go a long way in making our society, and the earth a better place to live, with a reduced rate of criminal activities. Physical paper cash is non-traceable, unaccountable, easy to hide or lose, steal, counterfeit, and spend without a trace. As such, paper cash has allowed all sorts of criminal activity to thrive. However, in a cashless economy, this will change with certain crimes almost eliminated. Violent crimes such as bank robberies, store holdups, armed robberies, employee cash theft, armour car heists, kidnap for ransom, and purse snatching would be significantly reduced, if not entirely eliminated, because carriage of Cash would be lite. The illegal drug trade and human trafficking are 'cash' businesses, and in a Cashless economy all illegal enterprises will be disrupted. There is also the reduced risk of transferring diseases. Citizens would be less likely to become ill due to contamination from bank notes and coins, as cash has been identified as disease carriers and medium of diseases transmission [16].Taking a consumer point of view, mobile payments contain some practical advantages in the form of queue avoidance, time, place independence, remote access to payment 
services, availability and increased speed [12].Judging the bank's perspective, the cashless society implies advantages in the form of savings. Cashiers and bank assistants would become superfluous and only a few assistants would be needed to assist at self-service counters. On the part of government and society this is however not desirable, as it means a reduction in the number of jobs with its inherent challenges such as crime and insecurity especially in an environment such as Nigeria.

Another advantage to the bank is the possibility of a reduction in card production costs when customers pay with their personal mobile phone or their personal payment card, information on the paper is transferred together with the money, thus omitting the need for loyalty, bonus and member cards.

\subsection{ACHIEVING CASHLESS SOCIETY IN NIGERIA}

The advantages of cashless society can be summarized along the same lines of reasons given by the Central Bank of Nigeria (CBN) for the introduction of new cash policy:

- To drive development and modernisation of our payment system in line with Nigeria's vision 2020 goal of being amongst the top 20 economics by the year 2020 .

- To reduce the cost of banking services (including cost of credit) and drive financial inclusion by providing more efficient transaction options and greater reach.

- To improve the effectiveness of monetary policy in managing inflation and driving economic growth.

- High cost of cash: There is a high cost of cash along the value chain from CBN and the banks, to corporations and traders; everyone bears the high costs associated with volume of cash handling.

- High risk of using cash: Cash encourages robberies and other cash-related crimes. It also can lead to financial loss in the case of fire and flooding incidents.

- High subsidy: CBN analysis showed that only $10 \%$ of daily banking transactions are $150 \mathrm{k}$, but the $10 \%$ account for majority of the high value transactions. These suggest that the entire banking population subsidizes the costs that the few population of $10 \%$ incurs in terms of high usage.

- Informal Economy: High cash usage results in a lot of money outside the formal economy, thus limiting the effectiveness of monetary policy in managing inflation and encouraging economic growth.

- Inefficiency \& Corruption: High cash usage enables corruption, leakages and money laundering amongst other cash related fraudulent activities.

Other benefits of the policy shift include to curb the following:

\subsection{DISADVANTAGES}

Despite the usefulness of the proposed technology, there are still some disadvantages of a Cashless Society as enumerated below:the disadvantages include that the unstable electronic value of money will become even more volatile especially, given that people will be conducting business with imaginary money.The government would be able to monitor purchases, spending habits and businesses patronised. Under this new system, the government will have a total control of our transaction and therefore exposing the privacy of individuals.Another issue concerns the transaction involving children with the challenge of determining the age at which such children will have for such transactions as accessing their substance 'pocket' money since it would need a 
mobile phone or a payment card to use store their money. A cashless society would therefore force parents to acquire mobile phones or payment cards for their children earlier than they may wish if they would want to give their children pocket money.

The proper handling of a mobile phone or payment card therefore becomes an additional challenge given that users must be able to remember details as personal identification number (PIN) and passwords. This might be a problem for elderly or illiterate people who might have to compromise privacy and divulge their personal codes in search of assistance.

Another issue is the possibility of theft. People are likely to lose mobile phones more than their wallets. In relation to this is the security issue. It is a fact that electronic systems designed by experts can be disassembled by others who have unwholesome intensions and used for bad antisocial [1].

\subsection{ICT AS DRIVERS}

ICTs are more than just computers or the Internet. Although, there has been a tendency to focus on Internet technology, the study of technology effects in economy and business fields must also be closely considered. Today, ICTs must be conceived broadly to encompass the information that businesses create and use, as well as the wide spectrum of increasingly convergent and linked technologies that process such information. Therefore, ICTs can be viewed as a collective term for a wide range of software, hardware, telecommunications and information management techniques which are used to create, produce, analyse, process, package, distribute, receive, retrieve, store and transform information [13].In particular, ICTs have a valuable potential for developing a cashless society through more effective use and better integration of ICTs in business processes while assisting them to make more efficient decisions relevant to their performance. ICTs have the potential to generate a step change in a Cashless society and make them more competitive and generate growth.Nowadays, economy must be understood as a global process. In this scenario, ICT can provide a wide variety of benefits to different firms. More specifically, ICT can reduce business cost, improve productivity and strengthen growth possibilities when a cashless society is introduced. Besides, the adoption and implementation of ICT by firms, it can also improve business relationships, quality and diffusion of knowledge in a cashless society.

\section{DATA AND METHODOLOGY}

The research design used in this study is the descriptive survey method. The population of this study is the entire academic community. A sample size of 100 was selected using the convenience sampling procedure. The sample includes both literate and illiterate Nigerians since they are the ones that can respond to determine the reliability of the numeracy of users knowing fully that an average Nigerians can use mobile phones. The method used to collect data for this study is structured questionnaire. A total of 100 copies of the questionnaire were personally administered out of which 87 copies were retrieved in usable form. This represents a response rate of $87 \%$. The responses from the respondents were collated and analysed using the simple percentage procedure. 


\section{ANALYSIS OF DATA}

The responses to the questions in the questionnaire provided the basis for the following analysis. Table 1, below presents responses to such questions as the respondents' awareness and preference for the cashless economy and its introduction in Nigeria.

Table 1: Knowledge of Cashless Economy to users Source: Field Survey

\begin{tabular}{|l|l|r|r|}
\hline & & Frequency & \multicolumn{1}{|c|}{ Percent } \\
\hline $\begin{array}{l}\text { I have heard about Nigerian's Cashless } \\
\text { Economy? }\end{array}$ & Strongly Agree & 36 & 41.4 \\
\hline & Agree & 41 & 47.1 \\
\hline & Undecided & 3 & 3.4 \\
\hline & Disagree & 6 & 6.9 \\
\hline & $\begin{array}{l}\text { Strongly } \\
\text { Disagree }\end{array}$ & 1 & 1.1 \\
\hline & Total & $\mathbf{8 7}$ & $\mathbf{1 0 0 . 0}$ \\
\hline $\begin{array}{l}\text { Cashless Economy should be introduced } \\
\text { in Nigeria. }\end{array}$ & Strongly Agree & 25 & 28.7 \\
\hline & Agree & 23 & 26.4 \\
\hline & Undecided & 16 & 18.4 \\
\hline & Disagree & 11 & 12.6 \\
\hline & Strongly & 9 & 10.3 \\
\hline & Disagree & 3 & 3.4 \\
\hline & Missing & $\mathbf{8 7}$ & $\mathbf{1 0 0}$ \\
\hline & Total & &
\end{tabular}

Table 1, above shows that there is a high degree of awareness among the populace about the cashless economy. 88\% of the respondents are aware of cashless economy in Nigeria. The reason for this high rate of awareness may not be unconnected with the nature of the sample selected. The study considered academic community which means, by all standards they are expected to be fairly aware of the happenings in the society. Few respondents however show a strong dislike for the cashless economy. While $55.1 \%$ of the respondents prefer that cashless economy should be introduced in Nigeria. The following reasons might have accounted for the low enthusiasm about its immediate introduction: the lack of preparedness for the system, the nation having other problems to solve now, freedom to use cash to any amount, inadequate technology, and that the flow of money will be hampered. Table 2, below presents the perceptions of benefits of the cashless economy by the respondents.

Table 2: Perceived Benefits of Cashless Economy Source: Field Survey

\begin{tabular}{|l|l|r|r|}
\hline & & Frequency & \multicolumn{1}{|c|}{ Percent } \\
\hline It would reduce risk of carrying cash & Strongly Agree & 35 & 40.2 \\
\hline & Agree & 35 & 40.2 \\
\hline & Undecided & 9 & 10.3 \\
\hline & Disagree & 5 & 5.7 \\
\hline & Strongly & 3 & 3.4 \\
\hline
\end{tabular}


International Journal of Information Sciences and Techniques (IJIST) Vol.3, No.2, March 2013

\begin{tabular}{|c|c|c|c|}
\hline & Disagree & & \\
\hline & Total & 87 & 100.0 \\
\hline \multirow[t]{7}{*}{ It would prevent money laundering. } & Strongly Agree & 20 & 23.0 \\
\hline & Agree & 28 & 32.2 \\
\hline & Undecided & 17 & 19.5 \\
\hline & Disagree & 10 & 11.5 \\
\hline & $\begin{array}{l}\text { Strongly } \\
\text { Disagree }\end{array}$ & 11 & 12.6 \\
\hline & Missing & 1 & 1.1 \\
\hline & Total & 87 & 100 \\
\hline \multirow[t]{7}{*}{ It can reduce corruption } & Strongly Agree & 13 & 14.9 \\
\hline & Agree & 23 & 26.4 \\
\hline & Undecided & 19 & 21.8 \\
\hline & Disagree & 19 & 21.8 \\
\hline & $\begin{array}{l}\text { Strongly } \\
\text { Disagree }\end{array}$ & 12 & 13.8 \\
\hline & Missing & 1 & 1.1 \\
\hline & Total & 87 & 100 \\
\hline \multirow[t]{7}{*}{ It can stimulate economic growth } & Strongly Agree & 18 & 20.7 \\
\hline & Agree & 31 & 35.6 \\
\hline & Undecided & 25 & 28.7 \\
\hline & Disagree & 8 & 9.2 \\
\hline & $\begin{array}{l}\text { Strongly } \\
\text { Disagree }\end{array}$ & 3 & 3.4 \\
\hline & Missing & 2 & 2.3 \\
\hline & Total & 87 & 100 \\
\hline
\end{tabular}

Table 2, shows that the most anticipated benefit of the cashless economy to Nigerians is its ability to reduce the risk of carrying cash around. $80.4 \%$ of the respondents believe that the most significant benefit of the cashless economy is reducing the risk of carrying cash as that is easily amenable to armed robbery, theft and misplacement. In the same spirit, 55.2\% of the respondents believe that the cashless economy will help fight against money laundering as the money flowing through the system can easily be traced and followed. $41.3 \%$ of the respondents believe that the cashless economy has something to contribute towards reducing corruption. This is because as significant amount of cash cannot change hands any more people will be forced to do things the proper way. Another envisaged benefit of the cashless economy is that it will stimulate economic growth as monies hitherto hidden in other illegitimate areas will now be freed up. $66.3 \%$ of the respondents believe that with the immergence of cashless economy, economic growth would be experienced. This is not far away from the reason why [18] made this statement that an efficient and modern payment system is positively correlated with the economic development and serves as a key enabler for economic growth .From the regulatory angle, this policy will also create an environment for more effective monetary policy implementation, create a more stable pricing system and curb the menace of inflation which is a determinant to the growth and development of any economy. Table 3, below present's responses to the question on the envisaged problems with the cashless economy. 
International Journal of Information Sciences and Techniques (IJIST) Vol.3, No.2, March 2013

Table 3: Perceived Problems of Cashless Economy

Source: Field survey

\begin{tabular}{|c|c|c|c|}
\hline & & Frequency & Percent \\
\hline \multirow[t]{7}{*}{ Limited point of sale } & Strongly Agree & 17 & 19.5 \\
\hline & Agree & 38 & 43.7 \\
\hline & Undecided & 18 & 20.7 \\
\hline & Disagree & 11 & 12.6 \\
\hline & $\begin{array}{l}\text { Strongly } \\
\text { Disagree }\end{array}$ & 2 & 2.3 \\
\hline & Missing & 1 & 1.1 \\
\hline & Total & 87 & 100 \\
\hline \multirow[t]{7}{*}{ The literacy required is basic numerals } & Strongly Agree & 17 & 19.5 \\
\hline & Agree & 33 & 37.9 \\
\hline & Undecided & 23 & 26.4 \\
\hline & Disagree & 9 & 10.3 \\
\hline & $\begin{array}{l}\text { Strongly } \\
\text { Disagree }\end{array}$ & 3 & 3.4 \\
\hline & Missing & 2 & 2.3 \\
\hline & Total & 87 & 100 \\
\hline \multirow[t]{6}{*}{ Increase in ATM snatchers } & Strongly Agree & 27 & 31.0 \\
\hline & Agree & 26 & 29.9 \\
\hline & Undecided & 15 & 17.2 \\
\hline & Disagree & 14 & 16.1 \\
\hline & $\begin{array}{l}\text { Strongly } \\
\text { Disagree }\end{array}$ & 5 & 5.7 \\
\hline & Total & 87 & 100.0 \\
\hline \multirow[t]{6}{*}{ Increase in Internet fraud } & Strongly Agree & 22 & 25.3 \\
\hline & Agree & 30 & 34.5 \\
\hline & Undecided & 21 & 24.1 \\
\hline & Disagree & 10 & 11.5 \\
\hline & $\begin{array}{l}\text { Strongly } \\
\text { Disagree }\end{array}$ & 4 & 4.6 \\
\hline & Total & 87 & 100.0 \\
\hline
\end{tabular}

Table 3, above shows that there are some problems which the respondents are envisaging to come with the cashless economy which may be informing their apparent unwillingness and lack of enthusiasm about the cashless economy. Limited points of sale came first as seen above, 63.2\% believe that the limited points of sale will hinder the free implementation of cashless economy. The researchers strongly believe this point to be true, except the government expedite actions on improving the existing infrastructure of the post of sale to as many registered shop owners as possible otherwise, there would be a challenge. $\quad 57.4 \%$ concurred that the basic literacy needed to operate the post of sale is just the numeracy techniques used for operating the mobile phones, which will ultimately increase the users of the cashless methods. $60.9 \%$ of the respondents believe that ATM snatcher will be on the rise because physical cash may not be readily available as usual. Internet fraud is the major problem to be tackled in the cashless economy as $59.8 \%$ of the respondents see exposure to fraudulent activities as a big problem to the actualization of cashless economy. 


\section{CONCLUSION AND RECOMMENDATIONS}

From the above stated analysis, it appears that much has already been done on the issue of awareness of cashless economy and that a sizeable proportion of the people are actually awaiting the introduction of the cashless economy. It also appears that many people actually agree with the government on the usefulness of the cashless economy. It is agreed that the cashless system will be helpful in the fight against corruption and money laundering. One most significant contribution of the cashless economy is that it is expected to reduce the risk associated with carrying cash. Since most transactions will now be settled electronically, people will have less need to move around with cash and therefore, loss of cash, theft and armed robbery will drastically reduce.One major problem in the working of the cashless economy is internet related fraud. Nigeria is a major hub of electronic fraud and this can only be expected to increase as we march into the cashless economy. A country as large as Nigeria should have a signed law preventing cybercrime. Numeracy illiteracy is also a major factor. The level of literacy in Nigeria is still very high. The cashless economy is effectively an e-economy and in any e-system there is almost no place for the non-literate. It is concluded among other things that since the world is moving from cash to a cashless one through the use of electronic- based transactions, it is imperative for Nigeria to move in the same direction. The benefits of the above suggestions include increased economic growth, greater financial inclusion, and faster access to capital; reduce risk of cash related crimes among others. To make for the smooth implementation of the cashless system in Nigeria, the following measures are recommended There is the need to intensify the public enlightenment programme about the cashless system so that everybody will be acquainted with the system before its introduction since it will affect everybody. Since there is a high rate of illiteracy, and all people must be brought into the system, the government should design special enlightenment programmes for the non-literates, using probably signs and symbols to educate this segment on how to operate the cashless system (post on sale vis-à-vis mobile phones). Nigeria should make concerted efforts to design an internet security framework to check online fraud so that the public can be assured and protected against cyber-attack and fraud. There should be a careful study of the system to determine the number of point of sales terminals that will ensure its smooth running in Nigeria so as to prevent unnecessary friction in the system. There should be adequate legislation on all aspects of the operations of the cashless system so that both the operators of the system and the public can be adequately protected.

\section{REFERENCES}

[1] R. J. Anderson. (2008)Security Engineering: A guide to Building Dependable Distributed Systems. Wiley

[2] Au, Y.A \& R.J, Kauffman. (2007). The economics of mobile payments; Understanding stakeholder issues for an emerging financial technology application. Electronic Commerce research and Pllication, Volume 7, issue 2, (pp. 141-164)

[3] D. Balaban. (2010). Sony Faces and Uncertain Market forlts FeliCa Technology. From NFC Times.Retrieved from http://www.nfctimes.com/news/chart-article-contactless-e- money-jaqpanfelica-chips

[4] E.V Buskirt.(2010). Why your Phone Can’t Really Replace Your Credit Card. Retrieved from wired.com http://www.wired.com/epicenter/2010/08/phone-credit/all/1

[5] S. Calrk. AT \& T, Verrizon, (2010). T-Mobile confirm Isis mobile payments joint venture, Retrieved from http://www.nearfieldcommunicationsworld 
International Journal of Information Sciences and Techniques (IJIST) Vol.3, No.2, March 2013

[6] T. Dahlberg, N. Mallat, J. Ondrus, \& A. Zmijewska . (2008) Past, present and future of mobile payments research: A literature review. Electronic Commerce Research and Applications, Volume, Issue 2, (pp. 165-181)

[7] EIU \& IBM (2010) Digital economy ranking 2010-Beyond e-readiness. Retrieved from http://www.graphics.eiu.com/upload/EIU_Digital_economy_2010_FINAL_WEB.pdf

[8] D. D. Garcia-Swartz, R. W, Hahnn, \& A. Layne-Farra.(2006). The move Towards a Cashless Society: Calculating the costs and Benefits. Review of Netwol Economics, Volume 5, Issue 2, (pp. 199-228)

[9] L.Gormes.Visa's Mobile Payments Plan, 2010. Retrieved from http://www.forbes.com/forbes/2010/1025/technology-mobile-payments-cellphones-fraud-visacalling.html

[10] D. Knights, F. Noble, T. Vurdubakis, \& H. Willmott (2007). Electronic Cash and Virtual Marketplace: Reflection on a Revolution Postponed. Organisation, Volume 14, Issue 6. (pp. 147-768)

[11] V.G. Kopytoff. (2010) For PayPal, the future is Mobile. Retrieved from http://www.nytimes.com/2010/11/29/technology/29paypal.html!_r=1\&ref=business

[12] N. Mallat. (2006). Exploring Consumer adoption of Mobile Payments- A Qualittative Study. Sprouts: Working Papers on Information Systems, Volume 6, Article 44.

[13] Jan Ondrus \& Yves Pigneur,(2006) “Towards A Holistic Analysis of Mobile Payments: A Multiple Perspectives Approach“, Electronic Commerce Research and Applications, Vol. 5, Issue 3, pp. 246257.

[14] K. Prashanth. (2004). PayPal’s Business Model. ECCH Collection, (pp.1-18)

[15] M. E. Porter, \& V. E. Miller,(1985). "How Information Gives you Comparative Advantage" Harvard Business Review (July-Aug.) 63 (4), 149-174

[16] Central Bank of Nigeria "Towards a cashlite Lagos" retrieved from www.cbn.gov.ng/cashlite

[17] European Payment Council (2010)

[18] S.L. Sanusi, 2012 Central Bank Governor http://www.voiceofnigeria.org/Nigeria/Cashless-Policyenabler-of-Economic-growth-Sanusi.html 